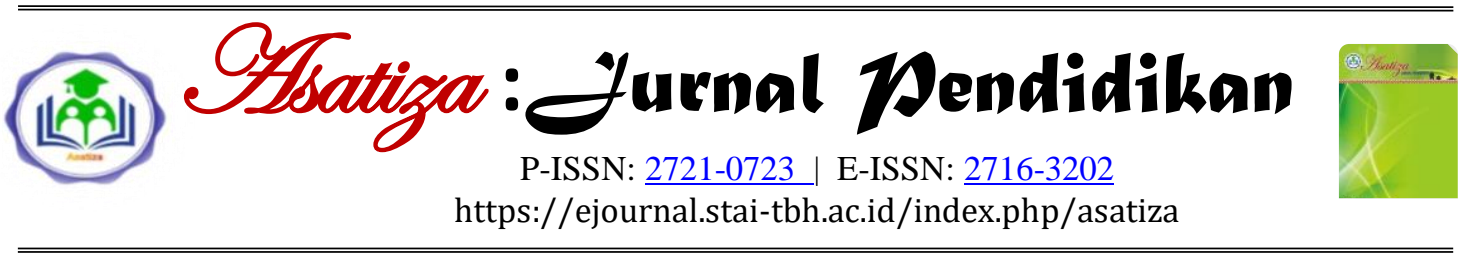

\section{Strategi Cooperative Learning Tipe Student Teams Achievement Division (STAD) pada Mata Pelajaran Bahasa Arab}

\author{
*Muhammad Wahyudi ${ }^{1, a}$, Abdul Rasyid Hidayat ${ }^{2, b}$ \\ ${ }^{1,2}$ Universitas Darussalam Gontor, Ponorogo, Jawa Timur, Indonesia \\ a muh.wahyudi@unida.gontor.ac.id, ${ }^{\mathrm{b}}$ abdulrasyidhidayat99@gmail.com
}

\begin{tabular}{|c|c|}
\hline $\begin{array}{l}\text { INFORMASI } \\
\text { ARTIKEL }\end{array}$ & \multirow{2}{*}{$\begin{array}{l}\text { Abstract } \\
\text { The Student Teams Achievement Division (STAD) strategy is very } \\
\text { important in learning Arabic because this method is student-centered, } \\
\text { active, cooperative, and helps each other complete assignments through }\end{array}$} \\
\hline Histori Artikel: & \\
\hline Diterima $\quad: 09 / 06 / 2021$ & \\
\hline Direvisi & TAD method in Arabic subjects. This paper was a literature study. The \\
\hline Disetujui $\quad: 27 / 09 / 2021$ & lata showed that the STAD is simpler than other cooperative learning \\
\hline Diterbitkan : 30/09 & rategies; it is a good model for teachers who are just starting to apply \\
\hline $\begin{array}{l}\text { Keywords: } \\
\text { STAD, Strategy, } \\
\text { Arabic Subject }\end{array}$ & $\begin{array}{l}\text { cooperative strategies in learning. The teachers should give attention to } \\
\text { each stage in STAD in innovative ways so that students do not feel bored } \\
\text { and can increase their learning motivation and learning outcomes. }\end{array}$ \\
\hline $\begin{array}{l}\text { Kata Kunci: } \\
\text { STAD, Strategi, } \\
\text { Bahasa Arab }\end{array}$ & $\begin{array}{l}\text { Abstrak } \\
\text { Strategi Student Teams Achievement Division (STAD) sangat penting } \\
\text { dalam pembelajaran Bahasa Arab karena metode ini berpusat pada siswa } \\
\text { sehingga siswa dapat lebih aktif, saling bekerja sama dan saling tolong }\end{array}$ \\
\hline $\begin{array}{l}\text { DOI: } \\
\text { https://doi.org/10.46963/ } \\
\underline{\text { asatiza.v2i3.340 }}\end{array}$ & $\begin{array}{l}\text { menolong menyelesaikan tugas dengan diskusi serta termotivasi karena } \\
\text { adanya penghargaan. Tujuan penelitian ini adalah untuk menggali } \\
\text { literatur tentang penerapan metode STAD pada mata pelajaran Bahasa } \\
\text { Arab. Jenis Penelitian ini merupakan penelitian Pustaka. Hasil Analisa }\end{array}$ \\
\hline $\begin{array}{l}\text { *Correspondence } \\
\text { Author: } \\
\text { muh.wahyudi@unida.go } \\
\text { ntor.ac.id }\end{array}$ & $\begin{array}{l}\text { data menunjukkan bahwa tipe STAD adalah salah satu pembelajaran } \\
\text { kooperatif yang lebih simpel dibanding dengan strategi kooperatif } \\
\text { lainnya, dan merupakan model yang bagus bagi guru yang baru mulai } \\
\text { mengaplikasikan strategi kooperatif dalam pembelajaran. Saran dari } \\
\text { penelitian ini adalah kepada guru hendaknya menerapkan setiap tahapan } \\
\text { pada STAD secara inovatif agar siswa tidak merasa bosan dan jenuh } \\
\text { sehingga dapat meningkatkan motivasi belajar dan hasil belajar juga } \\
\text { meningkat. }\end{array}$ \\
\hline
\end{tabular}

Cara mensitasi artikel:

Wahyudi, M., \& Hidayat, A. R. (2021). Strategi cooperative learning tipe student teams achievement division (STAD) pada mata pelajaran Bahasa Arab. Asatiza: Jurnal Pendidikan, 2(3), 197-205. https://doi.org/10.46963/asatiza.v2i3.340

\section{PENDAHULUAN}

Manusia merupakan makhluk homo socius, makhluk yang berkecenderungan untuk hidup bersama dan saling membutuhkan orang lain agar dapat memenuhi kebutuhan hidupnya. Secara langsung maupun tidak langsung manusia akan kesulitan tanpa kehadiran orang lain dan tidak dapat memaknai arti hidup yang sesungguhnya. Kehidupan bukan hanya tentang pribadi tetapi juga beberapa orang atau kelompok di dalamnya yang saling berhubungan secara timbal balik. Dalam membentuk hubungan sosial yang baik perlu adanya interaksi antar individu, rasa saling ketergantungan dan saling

Editorial Address: Kampus STAI Auliaurrasyidin Tembilahan 
mendukung satu sama lain. Dengan demikian, ikatan antar manusia sebagai makhluk sosial semakin terjalin dan memberikan pengaruh pada setiap proses perkembangannya. (Serjali \& Halim, 2020)

Ada berbagai aspek sosial yang dibutuhkan manusia dalam mencapai tugas perkembangannya. Bahwa salah satu aspek keterampilan sosial manusia adalah keterampilan untuk hidup dan bekerja sama. Hal ini juga dijadikan salah satu aspek penting dalam tugas perkembangan sosial pada masa remaja yang perlu dicapai dengan baik. Tugas perkembangan pada usia remaja yaitu remaja dapat mengembangkan keterampilan komunikasi in terpersonal, bergaul dengan teman sebaya secara berkelompok sehingga remaja bekerja sama dengan baik. (Muharamsyah, Hardhienata, \& Entang, 2017)

Pentingnya kemampuan kerja sama juga ditegaskan bahwa "there is no doubt that teams have a powerful impact on the performance of the employee and the future of organization" yang berarti tidak ada keraguan bahwa dalam tim atau kelompok memiliki dampak yang sangat kuat bagi kinerja karyawan dan masa depan sebuah organisasi. Pernyataanpernyataan tersebut dapat disimpulkan secara menyeluruh bahwa memiliki kemampuan bekerja sama dengan baik dalam kelompok serta mampu berinteraksi antar individu merupakan salah satu tugas perkembangan remaja yang harus dicapai secara optimal karena bekerja sama dalam kelompok dapat memberikan dampak yang sangat kuat bagi kelangsungan hidup remaja tersebut. (Zeng, Jing, Zhang, Matsui, \& Zhao, 2017)

Terdapat berbagai macam upaya untuk meningkatkan kemampuan kerja sama siswa. Metode cooperative learning adalah salah satu upaya dalam meningkatkan kemampuan kerja sama di mana metode ini berfokus pada penggunaan kelompok kecil siswa untuk bekerja sama dalam memaksimalkan kondisi belajar untuk mencapai tujuan. Selain itu metode ini juga disebut dengan pembelajaran gotong royong karena mengarahkan siswa untuk lebih aktif dan berdiskusi. Beberapa teknik dalam metode cooperative learning antara lain, Team Game Tournament, STAD, jigsaw, dan group investigation. Dari keempat teknik tersebut disebutkan bahwa teknik STAD dinilai lebih simpel dibandingkan dengan teknik lainnya dalam cooperative learning, namun memiliki pengaruh yang cukup baik dalam menumbuhkan kemampuan kerja sama. Teknik STAD juga menekankan pada kerja kelompok dan tanggung jawab bersama dalam mencapai tujuan dan adanya saling interaksi di antara anggota kelompok belajar (Yuliani, 2019; Masyudi, 2019).

Pelaksanaan teknik STAD dapat didukung dari beberapa penelitian terdahulu bahwa STAD dapat dijadikan salah satu alternatif metode bimbingan konseling serta efektif dalam meningkatkan interaksi sosial siswa. Penelitian ini menawarkan pelaksanaan metode tersebut sebagai sarana pembelajaran Bahasa Arab (Karno \& Safari, 2019). 
Model STAD adalah model pembelajaran alternatif yang layak digunakan sebagai salah satu metode pembelajaran Bahasa Arab. Didukung juga dari hasil penelitian yang menyatakan bahwa metode Student Team Achievement Division cukup serupa dengan Metode Langsung (direct method), sehingga secara teoritis dapat digunakan sebagai metode pembelajaran dalam bidang bahasa (Zahro, Amalia, \& Amin, 2020).

\section{METODE}

Penelitian ini merupakan kajian model pustaka. Dimulai dengan pengumpulan data literatur seputar konsep Student Teams Achievement Divisions (STAD) yang merupakan salah satu model Pembelajaran Koperatif (Cooperative Learning).

Data yang dikumpulkan, kemudian dipilah dan di analisa serta diklasifikasi. Tujuannya, menemukan inti teoritis dari konsep pembelajaran tersebut. Sehingga, bagi pendidikan yang ingin menggunakan metode ini mendapatkan manfaat teoritis dan praktis dalam melakukan evaluasi serta penelitian tentang tindakan kelas yang telah dilaksanakan sebagai penunjang pembelajarannya.

\section{HASIL DAN PEMBAHASAN \\ Pengertian Student Team Achievement Division (STAD)}

Cooperative learning adalah metode pembelajaran yang mampu mendorong sosialisasi, kompetisi sehat di kelas, kemampuan siswa untuk berinteraksi serta bekerja dengan siswa yang lain untuk mencapai tujuan yang sama. Tipe-tipe cooperative learning antara lain Team Game Tournament, jigsaw, Group
Investigation, Student Team Achievement Division. Bahwa tipologi pembelajaran koperatif tersebut, sejatinya termasuk dalam model permainan yang menarik dan dapat digunakan sebagai sarana pembelajaran bahasa. (Rahmawati, Nur, \& Taqiyuddin, 2021) STAD adalah salah satu dari tipe pembelajaran cooperative learning yang menekankan adanya kerja sama siswa secara berkelompok dalam memecahkan suatu masalah untuk mencapai tujuan belajar.

Metode pembelajaran cooperative learning identik dengan belajar kelompok. Sedangkan gagasan utama dari STAD adalah untuk memotivasi siswa supaya dapat saling mendukung dan membantu siswa lain dalam menguasai kemampuan yang diajarkan oleh guru. Model pembelajaran kooperatif STAD dipandang memadai dalam penelitian ini dengan alasan STAD merupakan salah satu strategi pembelajaran kooperatif yang lebih simpel dibanding dengan strategi kooperatif lainnya dan merupakan model yang bagus bagi guru yang baru mulai mengaplikasikan strategi kooperatif dalam pembelajaran. Model pembelajaran kooperatif teknik STAD tersebut menekankan pada kerja kelompok dan tanggung jawab bersama dalam mencapai tujuan dan adanya saling interaksi di antara anggota kelompok belajar. Pembelajaran kooperatif teknik STAD dicirikan oleh suatu struktur tugas, tujuan, dan penghargaan kooperatif. (Arara \& Taysum, 2020).

Metode pembelajaran ini mempengaruhi tingkat antusiasme siswa di dalam kelas. Bahwa strategi pembelajaran kooperatif memiliki 
Muhammad Wahyudi, \& Abdul Rasyid Hidayat

pengaruh yang efektif terhadap peningkatan ketrampilan kerja sama siswa dalam mata pelajaran Bahasa Arab. Diperkuat melalui penelitian terdahulu oleh (Antrakusuma, Haryono, \& Utomo, 2015) yang menyatakan bahwa pelaksanaan pembelajaran menggunakan Model STAD untuk meningkatkan hasil belajar siswa mengalami peningkatan dan berdampak baik terhadap aktivitas belajar siswa dikelas. Penelitian tersebut sebagai gambaran dan pendukung bahwa teknik ini layak diuji untuk meningkatkan kemampuan kerja sama siswa Pondok Pesantren KH Syamsuddin Ponorogo. (Antrakusuma, Haryono, \& Utomo, 2015)

Metode STAD membagi siswa di kelas ke dalam kelompok atau tim (4-5 orang) dengan anggota yang heterogen. Penerapan teknik STAD terdiri dari lima komponen utama pembelajaran yang membawa peserta didik pada suasana kerja sama yaitu sebagai berikut:

Presentasi kelas: Presentasi merupakan salah satu jenis pengajaran dalam kelas. Presentasi merupakan komunikasi satu arah, di mana informasi disampaikan kepada audiens oleh pembicara.

Kerja kelompok: Kerja kelompok atau belajar kelompok merupakan salah satu kegiatan dalam belajar yang dilakukan bersama-sama dengan masingmasing tugas-tugas. Tugas anggota kelompok adalah menguasai materi yang diberikan guru dan membantu teman satu kelompok untuk menguasai materi tersebut.

Kuis: Merupakan sarana evaluasi yang dikerjakan siswa secara mandiri. Tujuannya untuk menunjukkan apa saja yang telah diperoleh siswa selama belajar dalam kelompok. Hasil kuis digunakan sebagai nilai perkembangan individu dan disumbangkan dalam nilai kelompok.

Skor kemajuan individu: Merupakan nilai dari hasil-hasil kuis yang diadakan dalam belajar kelompok atau tes cepat setelah guru menjelaskan suatu materi. Hasil-hasil nilai tersebut bisa menambah nilai secara pribadi yang nantinya dapat memberikan kontribusi poin yang maksimal kepada timnya dalam sistem skor ini.

Rekognisi tim: Pemberian penghargaan kelompok (tim) berdasarkan pada rata-rata nilai perkembangan individu. Diambil dari nilai hasil individu yang dikelompokkan dengan hasil kerja kelompok maka akan didapat nilai kelompok sehingga bisa diberikan sebuah penghargaan kelompok terbaik. Tim akan mendapatkan sertifikat atau bentuk penghargaan yang lain apabila skor ratarata mereka mencapai kriteria tertentu

Berbagai model strategi tersebut, disimpulkan dari penelitian yang terdahulu. Khususnya bidang pembelajaran bahasa (Antrakusuma, Haryono, \& Utomo, 2015) (Yuliani, 2019) (Masyudi, 2019). Selanjutnya, adalah paparan mengenai aspek terpenting dalam STAD, yakni kajian tentang beberapa urgensi tentang penerapan kerja sama dalam metode pembelajaran STAD tersebut.

\section{Kemampuan Bekerja Sama}

Kemampuan pribadi, yaitu kapasitas seorang individu untuk melakukan beragam tugas dalam suatu pekerjaan. Kemampuan adalah kesanggupan, kecakapan, kekuatan kita berusaha dengan 
upaya dari diri sendiri. (Daniel, 2016) Kemampuan adalah sebuah penilaian terkini atas apa yang dapat dilakukan seseorang. Dapat disimpulkan bahwa kemampuan adalah suatu kecakapan, kesanggupan, dan kekuatan untuk melakukan sesuatu dalam rangka aktualisasi diri, pemecahan masalah dan pencapaian tujuan.

Seseorang yang memiliki kemampuan akan dapat dengan baik mencapai tujuan yang diinginkan namun sebaliknya apabila kemampuan tidak dapat secara maksimal diaktualisasikan maka akan menjadi penyebab timbulnya kegagalan. Kegagalan dapat dicegah melalui upaya saling mencerdaskan antar sesama dalam bentuk hubungan antar anggota pada kelompok yang saling bekerja sama. Melalui kerja sama, manusia dapat saling memberi, saling mengisi, dan saling menghargai. Keuntungan bekerja sama dalam pembelajaran bagi siswa adalah siswa dapat saling memberi dan mengisi dengan teman sendiri dalam upaya memahami suatu pengetahuan. Ini adalah sebagian dari pola yang digunakan dalam STAD. (Yuliani, 2019) (Masyudi, 2019)

\section{Tujuan Kerja Sama}

Kerja sama sebagai kerja secara tim membuat lebih cepat dan efisien akan tetapi memiliki tujuan lainnya yang mendalam. kerja sama memiliki tujuan diantaranya yaitu: 1) Memberikan pendapat tentang permasalahan dengan pertanyaan, wawasan dan pemecahan dalam kelompok, 2) Bertukar pikiran antara teman yang satu dengan teman yang lain sehingga teman yang tadinya tidak tahu akan menjadi tahu, 3) Meringankan pekerjaan yang di dapat dengan membagi tugas pada kelompok, 4) Cepat terselesaikan pekerjaan karena dilakukan dengan bersama-sama, 5) Menyatukan ide, gagasan ataupun pendapat kelompok dalam keputusan bersama (Rahmawati, Nur, \& Taqiyuddin, 2021)

Tujuan dari kerja sama menurut rumusan di atas dapat menjadikan sebuah pekerjaan akan menjadi lebih mudah karena dipecahkan bersama dalam sebuah kelompok serta adanya pertukaran pendapat dan penyatuan ide gagasan di dalamnya yang membuat tingkat efisiensi dan efektivitas lebih tinggi dibandingkan dengan kerja secara individual. Kerja tim/kerja sama adalah strategi yang memiliki potensi untuk meningkatkan kinerja individu dan pengorganisasian (Ingram, 2000) dalam (Manzoor, Ullah, Hussain, \& Ahmad, 2011) Manzoor dkk (2011). Melalui proses kerja sama siswa akan menyadari kekurangan dan kelebihan yang dimilikinya, saling membantu dan saling mengisi satu sama lain serta persaingan yang positif untuk mencapai prestasi belajar yang optimal.

\section{Pentingnya Kerja Sama dalam} Pendidikan

Penelitian menunjukkan bahwa kemampuan kerja sama penting dimiliki oleh setiap siswa pada jenjang pendidikan Sekolah Dasar karena hal tersebut mampu melatih siswa dalam memahami, merasakan, dan melaksanakan aktivitas kerja sama guna mencapai tujuan bersama. Selain itu kemampuan kerja sama mampu meningkatkan rasa percaya diri dan kemampuan berinteraksi, serta melatih siswa beradaptasi dengan lingkungan baru. 
Pentingnya kerja sama ternyata tidak hanya sebatas pada pendidikan dasar saja akan tetapi telah menjadi sebuah paradigma dalam dunia pendidikan yang mana kerja sama menjadi salah satu aspek penting di dalamnya. Hal ini dijelaskan bahwa paradigma pendidikan abad 21 menekankan pada kemampuan peserta didik untuk mencari tahu dari berbagai sumber, merumuskan permasalahan, berpikir analitis dan kerja sama serta kolaborasi dalam menyelesaikan masalah dan juga dijelaskan dalam frame work mengenai pembelajaran abad 21 point (b) Kemampuan berkomunikasi dan bekerjasama (Communication and Collaboration skills). Hal ini dapat disimpulkan bahwa dalam menghadapi pendidikan di era 21 ini kemampuan kolaborasi atau kerja sama adalah salah satu aspek penting bagi siswa dalam menjawab tantangan di era yang semakin berkembang ini. (Febriani, Wildana Wargadinata, Syuhadak, \& Ibrahim, 2020)(Rahmawati, Nur, \& Taqiyuddin, 2021)

\section{Indikator kemampuan kerja sama:}

Indikator kemampuan kerja sama dapat dilihat dari 5 hal penting, yaitu:

1. Kemampuan mendeskripsikan, yaitu kemampuan atau kecakapan individu dalam menggambarkan dan memaparkan suatu hal atau kondisi tertentu dengan jelas dan rinci.

2. Kemampuan orientasi masalah, yaitu kemampuan individu untuk menghadapi berbagai permasalahan yang muncul ketika bekerja sama dengan orang lain.

3. Kemampuan berempati, yaitu kemampuan individu memahami perasaan dan emosi orang lain serta menempatkan diri pada kondisi dan sudut pandang mereka sehingga dapat merasakan apa yang dirasakan orang lain.

4. Kemampuan persamaan, yaitu kemampuan individu dalam mencapai tujuan bersama dalam menyelesaikan tugas.

5. Kemampuan untuk bersikap profesional, yaitu kemampuan seseorang dalam membedakan kebutuhan sendiri dan orang lain dan bertanggung jawab atas tugasnya. (Arara \& Taysum, 2020)

\section{Upaya Meningkatkan Kemampuan} Kerja Sama dalam Penyelesaian Studi

Terdapat berbagai macam upaya dalam meningkatkan kemampuan kerja sama khususnya dalam penyelesaian studi. Kemampuan kerja sama siswa dalam pembelajaran dapat dilakukan melalui tutor sebaya yaitu meliputi kinerja kelompok dalam penyelesaian tugas kelompok, kemampuan kelompok dalam memecahkan dan kemampuan kelompok dalam menjawab pertanyaan dari kelompok lain.

Upaya peningkatan kemampuan kerja sama siswa dapat dicapai melalui pembelajaran kooperatif Tipe numbered Heads Together (NHT). Adapun langkahlangkah tipe NHT yaitu perencanaan, tindakan, observasi, dan refleksi. Menurut Rosita \& Leonardo menjelaskan bahwa peningkatan kemampuan kerja sama dapat dilakukan dengan menggunakan metode pembelajaran kooperatif dengan tipe Think Pair Share yaitu dengan memberi siswa waktu yang lebih banyak untuk berpikir, 
menjawab dan saling membantu. (Mustami, Khalifah, \& Safitri, 2018)

Melalui pembelajaran kooperatif tipe STAD ditemukan adanya peningkatan pada kemampuan kerja sama dan hasil belajar siswa sehingga STAD dapat dijadikan sebagai salah satu pilihan pembelajaran yang menekankan pada kegiatan kelompok sehingga dapat meningkatkan kerja sama siswa. Dengan demikian dapat disimpulkan bahwa terdapat berbagai macam upaya untuk meningkatkan kemampuan kerja sama siswa di mana karakteristik dari siswa serta masalah yang terjadi pada tiap tempat juga menjadi faktor pendukung dalam menentukan jenis upaya yang akan diberikan. (Masyudi, 2019)

\section{SIMPULAN}

Pembelajaran kooperatif dapat dijadikan sebagai upaya meningkatkan perilaku bekerja sama di mana pembelajaran kooperatif dibentuk melalui pembentukan kelompok-kelompok kecil di dalam kelas yang heterogen, terdiri dari empat sampai lima peserta didik dalam setiap kelompoknya diikuti dengan pemberian bantuan individu bagi yang memerlukannya. Adapun tipe-tipe dari kooperatif learning adalah Team Game Tournament, jigsaw, Group Investigation, dan Student Team Achievement Division (STAD). (Rahmawati, Nur, \& Taqiyuddin, 2021)

Dari keempat tipe pembelajaran kooperatif tersebut, bahwa tipe STAD adalah salah satu pembelajaran kooperatif yang lebih simpel dibanding dengan strategi kooperatif lainnya dan merupakan model yang bagus bagi guru yang baru mulai mengaplikasikan strategi kooperatif dalam pembelajaran. Langkah-langkah dari tipe STAD ini meliputi presentasi kelas, kerja kelompok, kuis, skor kemajuan individu, dan rekognisi tim. STAD ini menekankan adanya pemberian penghargaan pada siswa atau kelompok terbaik sehingga dapat menstimulus siswa untuk lebih bersemangat dalam proses belajar. Adapun penerapan pembelajaran STAD ini dapat dilakukan pada pelaksanaan pemberian layanan dalam bimbingan konseling.

Dari pernyataan di atas dapat disimpulkan bahwa tipe pembelajaran STAD dapat dijadikan upaya untuk meningkatkan kemampuan kerja sama serta dapat digunakan sebagai alternatif metode oleh guru bimbingan konseling dalam memberikan layanan bimbingan dan konseling di sekolah.

\section{REFERENSI}

Antrakusuma, B., Haryono, H., \& Utomo, S. B. (2015). Pembelajaran model student team achievement division (stad) berbantuan e-learning untuk meningkatkan aktivitas dan prestasi belajar siswa pada materi redoks Kelas X MIA 3 SMA Negeri 1 Teras Tahun Pelajaran 2014/2015. Jurnal Pendidikan Kimia, 4(4), 200-206. Retrieved from https://jurnal.fkip.uns.ac.id/index.php /kimia/article/view/6664

Arara, K., \& Taysum, A. (2020). From hierarchical leadership to a mark of distributed leadership by whole school inquiry in partnership with Higher Education Institutions: comparing the Arab education in Israel with the education system in England. International Journal of Leadership in Education, 23(6), 755774. 
Muhammad Wahyudi, \& Abdul Rasyid Hidayat

https://doi.org/10.1080/13603124.20 19.1591513

Daniel, E. (2016). The usefulness of qualitative and quantitative approaches and methods in researching problem-solving ability in science education curriculum. Journal of Education and Practice, 7(15), 91-100. Retrieved from https://eric.ed.gov/?id=EJ1103224

Febriani, S. R., Wildana Wargadinata, Syuhadak, S., \& Ibrahim, F. M. (2020). Design of arabic learning for senior high school in the $21 \mathrm{st}$ Century. Jurnal Al Bayan: Jurnal Jurusan Pendidikan Bahasa Arab, 12(1), 1-21. https://doi.org/10.24042/albayan.v12i 1.5886

Karno, A. F., \& Safari, M. (2019). (Student Team Achievment إستر اتيجية لنطوير النشاط Divisions) و الدو افع في هادة الوطالعة لطلاب قسن تعلين الطين

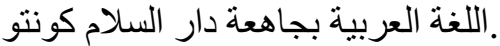
Multaqa Nasional Bahasa Arab II, 2 (1). Retrieved from http://munasbauai.com/index.php/mn ba/article/view/58

Manzoor, S. R., Ullah, H., Hussain, M., \& Ahmad, Z. M. (2011). Effect of Teamwork on Employee Performance. International Journal of Learning and Development, 1(1). 110-126. https://doi.org/10.5296/ijld.v1i1.1110

Masyudi. (2019). Strategi pembelajaran kooperatif model student teams achievement division (STAD) terhadap hasil belajar bahasa arab. Tawazun: Jurnal Pendidikan Islam, 11(2), 247-62. Retrieved from http://ejournal.uikabogor.ac.id/index.php/TAWAZUN/ar ticle/view/1672
Muharamsyah, D., Hardhienata, S., \& Entang, M. (2017). Penerapan model student teams achievement divisions (STAD) dan think pair square (TPS) untuk meningkatkan ketrampilan berbicara dan menulis bahasa arab pada siswa kelas X SMA Terpadu Al-Ma'shum Mardiyah Cianjur. Jurnal Manajemen Pendidikan, 4(1), 27-37. doi:10.33751/jmp.v4i1.416

Mustami, Khalifah, M., \& Safitri, D. (2018). The effects of numbered heads together-assurance relevance interest assessment satisfaction on students' motivation. International Journal of Instruction, . Retrieved from https://eric.ed.gov/?id=EJ1183397

Rahmawati, F. A., Nur, I. R., \& Taqiyuddin, M. (2021). Creative language games for enjoyable arabic teaching 1 al-al'ab al-lughawiyyah alibda'iyyah li ta'lim al-lughah al'arabiyyah al-mumti'ah. Jurnal Al Bayan: Jurnal Jurusan Pendidikan Bahasa Arab, 13(1). 108-128. https://doi.org/10.24042/albayan.v13i 1.6917

Serjali, N. A., \& Halim, H. A. (2020). The effectiveness of student team achievement divisions (STAD) model towards students' achievement in the Principles of Accounting subject. International Business Education Journal, 1-14. https://doi.org/10.37134/ibej.vol13.sp .1 .2020

Yuliani, N. (2019). The role of student teams achievement divisions (STAD) in improving student's learning outcomes. Classroom Action Research Journal (CARJO), 3(1), 815. Retrieved from 
http://journal2.um.ac.id/index.php/ca rjo/article/view/8031

Zahro, U. C., Amalia, S. R., \& Amin, N. F. (2020). The effectiveness of direct method in arabic language learning. Jurnal Al Bayan: Jurnal Jurusan Pendidikan Bahasa Arab, 12(1), 149164.

https://doi.org/10.24042/albayan.v12i 1.5775

Zeng, Jing, Zhang, W., Matsui, Y., \& Zhao, X. (2017). The impact of organizational context on hard and soft quality management and innovation performance.

International Journal of Production Economics, 240-251. https://doi.org/10.1016/j.ijpe.2016.12 .031 